University of Nebraska - Lincoln

DigitalCommons@University of Nebraska - Lincoln

\title{
Evidence for multiple modes of uranium immobilization by an anaerobic bacterium
}

\author{
Allison E. Ray \\ Idaho State University, alikona.ray@gmail.com \\ John R. Bargar \\ Stanford Synchrotron Radiation Lightsource \\ Vaideeswaran Sivaswamy \\ Washington State University \\ Alice C. Dohnalkova \\ Pacific Northwest National Laboratory \\ Yoshiko Fujita \\ Idaho National Laboratory \\ See next page for additional authors
}

Follow this and additional works at: https://digitalcommons.unl.edu/usdoepub

Part of the Bioresource and Agricultural Engineering Commons

Ray, Allison E.; Bargar, John R.; Sivaswamy, Vaideeswaran; Dohnalkova, Alice C.; Fujita, Yoshiko; Peyton, Brent M.; and Magnuson, Timothy S., "Evidence for multiple modes of uranium immobilization by an anaerobic bacterium" (2011). US Department of Energy Publications. 176.

https://digitalcommons.unl.edu/usdoepub/176

This Article is brought to you for free and open access by the U.S. Department of Energy at DigitalCommons@University of Nebraska - Lincoln. It has been accepted for inclusion in US Department of Energy Publications by an authorized administrator of DigitalCommons@University of Nebraska - Lincoln. 


\section{Authors}

Allison E. Ray, John R. Bargar, Vaideeswaran Sivaswamy, Alice C. Dohnalkova, Yoshiko Fujita, Brent M. Peyton, and Timothy S. Magnuson 


\title{
Evidence for multiple modes of uranium immobilization by an anaerobic bacterium
}

\author{
Allison E. Ray ${ }^{\mathrm{a}, \mathrm{b}, *}$, John R. Bargar ${ }^{\mathrm{c}}$, Vaideeswaran Sivaswamy ${ }^{\mathrm{d}, 1}$, \\ Alice C. Dohnalkova ${ }^{\mathrm{e}}$, Yoshiko Fujita ${ }^{\mathrm{b}}$, Brent M. Peyton ${ }^{\mathrm{d}, 2}$, Timothy S. Magnuson ${ }^{\mathrm{a}}$ \\ ${ }^{\text {a }}$ Department of Biological Sciences, Idaho State University, Pocatello, ID 83209, USA \\ ${ }^{\mathrm{b}}$ Biological Systems Department, Idaho National Laboratory, Idaho Falls, ID 83415, USA \\ ${ }^{c}$ Stanford Synchrotron Radiation Lightsource, 2575 Sand Hill Rd., Menlo Park, CA 94025, USA \\ ${ }^{\mathrm{d}}$ Center for Multiphase Environmental Research and Department of Chemical Engineering, Washington State University, P.O. Box 642719, \\ Pullman, WA 99164-2719, USA \\ ${ }^{\mathrm{e}}$ Environmental Molecular Sciences Laboratory, Pacific Northwest National Laboratory, Richland, WA 99352, USA
}

Received 19 March 2010; accepted in revised form 9 February 2011; available online 2 March 2011

\begin{abstract}
Microbial reduction of hexavalent uranium has been studied widely for its potential role in bioremediation and immobilization of soluble U(VI) in contaminated groundwater. More recently, some microorganisms have been examined for their role in immobilization of $\mathrm{U}(\mathrm{VI})$ via precipitation of uranyl phosphate minerals mediated by microbial phosphate release, alleviating the requirement for long-term redox control. Here, we investigated the mechanism of U(VI) removal mediated by an environmental isolate, strain UFO1, that is indigenous to the Field Research Center (FRC) in Oak Ridge, TN and has been detected in U(VI)contaminated sediments. Changes in U(VI) speciation were examined in the presence and absence of the electron-shuttling moiety, anthraquinone-2,6-disulfonate (AQDS). Cell suspensions were capable of nearly complete removal of $100 \mu \mathrm{M}$ U(VI) from solution within $48 \mathrm{~h}$; U(VI) removal was not dependent on the presence of an exogenous electron donor or AQDS, although AQDS increased the rate of U(VI) removal. X-ray Absorption Near Edge Structure (XANES) and Extended X-ray Absorption Fine Structure (EXAFS) spectroscopic measurements indicated that U(IV) was the predominant oxidation state of uranium in cell suspensions in both the absence and presence of $100 \mu \mathrm{M}$ AQDS. Interestingly, $17 \%$ of the cell-associated precipitates in a U(VI)-treated suspension that lacked AQDS had spectral characteristics consistent with a uranyl phosphate solid phase. The potential involvement of phosphate was consistent with observed increases in soluble phosphate concentrations over time in UFO1 cell suspensions, which suggested phosphate liberation from the cells. TEM-EDS confirmed the presence of uranyl phosphate with a U:P ratio consistent with autunite (1:1). EXAFS analyses further suggested that U(IV) was bound to low-Z neighbors such as $\mathrm{C}$ or $\mathrm{P}$, inferred to be present as functional groups on biomass. These results suggest that strain UFO1 has the ability to facilitate $\mathrm{U}(\mathrm{VI})$ removal from solution via reductive and phosphate precipitation mechanisms. Both mechanisms offer potential for the remediation of U-contaminated sediments at the FRC or elsewhere.
\end{abstract}

(C) 2011 Elsevier Ltd. All rights reserved.

\footnotetext{
* Corresponding author. Present address: Biofuels and Renewable Energy Technologies, Idaho National Laboratory, P.O. Box 1625, Idaho Falls, ID 83415, USA. Tel.: +1 208526 4554; fax: +12085260828 .

E-mail address: alikona.ray@gmail.com (A.E. Ray).

${ }^{1}$ Present address: NLC Nalco India Limited, 20A Park Street, Kolkata 700016, India.

2 Present address: Department of Chemical and Biological Engineering, Montana State University, Bozeman, MT 59717, USA.
}

\section{INTRODUCTION}

Uranium is a major soil and groundwater contaminant at 12 of the 18 major Department of Energy (DOE) facilities due to nuclear fuels and weapons production and waste reprocessing (Riley et al., 1992). At Area 3 of the former DOE Field Research Center (FRC; currently the site is known as the Oak Ridge Integrated Field-Research

0016-7037/\$ - see front matter ( 2011 Elsevier Ltd. All rights reserved. doi:10.1016/j.gca.2011.02.040 
Challenge site) established at the Y-12 Facility at Oak Ridge National Laboratory (ORNL) in Tennessee, measured uranium concentrations have been as high as $\sim 50 \mathrm{mg} / \mathrm{L}$ in groundwater and $800 \mathrm{mg} / \mathrm{kg}$ in aquifer solids (Wu et al., 2006). The mobility of uranium and the risk it poses to the environment depend upon its chemical speciation. Under typical environmental conditions, uranium primarily exists in two oxidation states, U(VI) and U(IV) (Geipel, 2005). Hexavalent uranium is much more soluble than the reduced form, $\mathrm{U}(\mathrm{IV})$, and is often present as $\mathrm{U}(\mathrm{VI})$-carbonate complexes in groundwater (Brooks et al., 2003). Under anoxic conditions, U(IV) is stable in the form of the mineral uraninite $\left(\mathrm{UO}_{2}(\mathrm{~s})\right)$, but upon exposure to oxidizing conditions, uraninite is prone to oxidation (Langmuir, 1978). The susceptibility of uraninite to oxidation makes it potentially unstable in subsurface environments (Fayek et al., 2002). As a result, remediation approaches that rely on $\mathrm{U}(\mathrm{VI})$ reduction to $\mathrm{U}(\mathrm{IV})$ may provide only temporary results if the redox conditions cannot be sustained.

In addition to redox reactions, adsorption/desorption, precipitation/dissolution, and complexation reactions also influence the fate of uranium in natural environments (Langmuir, 1978). Uranyl readily adsorbs to iron oxide minerals and can form complexes with organic matter as well as with inorganic ligands (Elless and Lee, 1998). In carbonate environments, strong aqueous complexes (e.g., $\left.\mathrm{UO}_{2}\left(\mathrm{CO}_{3}\right)_{2}^{2}-\right)$ are formed that enhance $\mathrm{U}(\mathrm{VI})$ mobility (Langmuir, 1978). If sufficient phosphate is present, uranyl can also precipitate in phosphate minerals, such as autunite $\left(\mathrm{Ca}\left(\mathrm{UO}_{2}\right)_{2}\left(\mathrm{PO}_{4}\right)_{2}\right)$, which are stable at $\mathrm{pH}$ values ranging from 5 to 8.5 (Langmuir, 1978).

Due to the vast scope of environmental contamination by uranium there is intense interest in the development of effective remediation methods. Bioremediation methods are among those that have attracted attention in recent years (Finneran et al., 2002; Istok et al., 2004; Lovley, 1995). Bacteria can affect the fate of uranium in subsurface environments by a variety of mechanisms, including direct or indirect reduction of $\mathrm{U}(\mathrm{VI})$ to $\mathrm{U}(\mathrm{IV})$, oxidation of $\mathrm{U}(\mathrm{IV})$ to $\mathrm{U}(\mathrm{VI})$, sorption and/or accumulation of U(VI) by cells, and release of phosphate that induces precipitation of $\mathrm{U}(\mathrm{VI})$ in phosphate minerals.

Microbial reduction of hexavalent uranium has been studied extensively with metal and sulfate-reducing organisms such as Geobacter metallireducens, Shewanella putrefaciens, Desulfovibrio spp., Cellulomonas spp., Desulfosp orosinus spp., and Deinococcus radiodurans (Fredrickson et al., 2000a,b; Gorby and Lovley, 1992; Spear et al., 1999; Sani et al., 2002, 2004; Suzuki et al., 2003, 2004). Indirect reduction of $\mathrm{U}(\mathrm{VI})$ can be mediated by humic acids ( $\mathrm{Gu}$ et al., 2005), the electron-shuttling humic acid analog, anthraquinone-2,6-disulfonate (AQDS), or Fe(II) (Fredrickson et al., 2000a,b). Other research has shown that bacteria may be effective biosorbents for uranium. Rapid removal of $\mathrm{UO}_{2}^{2}+$ from solution was seen in the presence of Pseudomonas fluorescens (Bencheikh-Latmani et al., 2003) and Bacillus subtilis (Fowle et al., 2000), and the mode of uranium removal was postulated to be adsorption to the cell wall. A recent study has suggested the removal of
$\mathrm{U}(\mathrm{VI})$ in microbially-reduced sediments could be attributed to the U(VI) sorptive capacity of bacteria in the phylum Firmicutes (N'Guessan et al., 2008). An Arthrobacter isolate from a uranium-contaminated site was capable of accumulating uranium intracellularly as precipitates closely associated with polyphosphate granules (Suzuki and Banfield, 2004). Other studies have examined the role of phosphatase in the bioprecipitation of uranyl phosphate resulting from hydrolysis of polyphosphate ( Macaskie et al., 1992; Thomas and Macaskie, 1996; Basnakova et al., 1998) and secretion of phosphate by Citrobacter sp. and Pseudomonas aeruginosa (Macaskie et al., 2000; Renninger et al., 2004). More recently, Rahnella and Bacillus isolates from the FRC were shown to hydrolyze glycerol-3phosphate and precipitate uranyl as an autunite mineral in aerobic cell suspensions (Beazley et al., 2007). Cellulomonas strain ES6 has shown the ability to remove soluble uranium from solution by $\mathrm{U}(\mathrm{VI})$ reduction and uranyl phosphate precipitation mechanisms (Sivaswamy et al., 2011). It appears that numerous organisms are capable of immobilizing U(VI) by one or more mechanisms, although the current literature generally highlights only single mechanisms for organisms that are studied. It is possible that multiple processes operate simultaneously, which is important not only with respect to treatment effectiveness, but also with respect to understanding the best approach for treatment and susceptibility to reversal.

In situ biological treatment is an attractive option for the remediation of uranium-contaminated sites because it could potentially be less expensive and less disruptive than traditional ex situ technologies, and it relies on indigenous microorganisms to achieve clean-up of hazardous wastes (NABIR, 2003). Recent studies have demonstrated the successful use of carbon substrate amendments to stimulate reduction of $\mathrm{U}(\mathrm{VI})$ by indigenous microbial communities during in situ bioremediation field tests (Senko et al., 2002; Istok et al., 2004; North et al., 2004; Chang et al., 2005; Vrionis et al., 2005; Wu et al., 2006, 2007).

As part of an effort to identify and characterize indigenous microorganisms with the potential to be used for in situ bioremediation, we isolated strain UFO1 from sediments at the FRC in Oak Ridge, TN. UFO1 is a novel representative of the newly described genus of fermentative bacteria, Pelosinus, with demonstrated metal-reducing capabilities (Ray, 2007; Ray et al., 2010). UFO1 was isolated from pristine sediments collected from the background area of the FRC. Clones with high 16S rRNA gene sequence similarity to strain UFO1 have been detected in Fe(III)-reducing enrichments (Petrie et al., 2003) and sulfate-reducing enrichments initiated with U(VI)-contaminated FRC sediments (Nyman et al., 2007). Here, we report on our studies that show cell suspensions of UFO1 can affect uranium speciation and can remove U(VI) from aqueous solution. We examined the mode of U(VI) removal using X-ray absorption spectroscopy (XAS) and transmission electron microscopy coupled with energy dispersive spectroscopy (TEM-EDS) to characterize U-containing precipitates formed in cell suspensions treated with $100 \mu \mathrm{M} \mathrm{U}(\mathrm{VI})$ in the presence and absence of the humic acid analog, AQDS. Our results indicate that UFO1 can 
mediate aqueous $\mathrm{U}(\mathrm{VI})$ removal via both reductive and redox-neutral mechanisms. These findings support the potential for fermentative bacteria to play a role in remediation of environments contaminated with uranium.

\section{METHODS}

\subsection{Cultures and media}

Strain UFO1 was routinely cultured in anoxic R2 broth at $30{ }^{\circ} \mathrm{C}$. R2 broth was prepared from a dry mix (BD Diagnostic Systems, Franklin Lakes, NJ) or as follows (per liter): $0.5 \mathrm{~g}$ yeast extract; $0.5 \mathrm{~g}$ proteose peptone; $0.5 \mathrm{~g}$ casamino acids; $0.5 \mathrm{~g}$ glucose; $0.5 \mathrm{~g}$ soluble starch; $0.3 \mathrm{~g}$ sodium pyruvate; $0.3 \mathrm{~g} \mathrm{~K}_{2} \mathrm{HPO}_{4} ; 0.05 \mathrm{~g} \mathrm{MgSO}_{4}$ (Reasoner and Geldreich, 1985) and adjusted to $\mathrm{pH}$ 7. Anoxic R2 broth was prepared by boiling and cooling under a headspace of $\mathrm{N}_{2}$, dispensing into anaerobic pressure tubes, serum vials, or flasks with a headspace of $\mathrm{N}_{2}$, sealing with thick butyl-rubber stoppers, and autoclaving.

The removal of soluble U(VI) from solution by strain UFO1 was evaluated using a bicarbonate-buffered medium. Anaerobic bicarbonate buffer $(30 \mathrm{mM} \mathrm{NaHCO} ; 1.3 \mathrm{mM}$ $\mathrm{KCl}$ ) was prepared by boiling, then cooling and bubbling under an $\mathrm{O}_{2}$-free stream of $\mathrm{N}_{2}: \mathrm{CO}_{2}(80: 20)$, and autoclaving. The bicarbonate buffer had a final $\mathrm{pH}$ of 7 . Bicarbonate buffer was used for washing and re-suspending cells. All glassware for uranium removal experiments was acidwashed in $10 \% \mathrm{HNO}_{3}$ and thoroughly rinsed in deionized water.

\subsection{Uranium removal and phosphate release experiments}

For uranium removal experiments, cells were grown for 24 hours in $\mathrm{R} 2$ broth with reduced phosphate content $\left(0.003 \mathrm{~g} / \mathrm{L}\right.$ vs. $\left.0.3 \mathrm{~g} / \mathrm{L} \mathrm{K}_{2} \mathrm{HPO}_{4}\right)$. Cells were harvested by centrifugation at $8000 \mathrm{~g}$ for $20 \mathrm{~min}$. The supernatant was discarded and the cell pellets were suspended in anaerobic bicarbonate buffer that was free of added phosphate with all transfers occurring in an anaerobic glove box $(90 \%$ $\mathrm{N}_{2} ; 5 \% \mathrm{H}_{2} ; 5 \% \mathrm{CO}_{2}$ ). This process was performed three times and the cells were then re-suspended under nongrowth conditions in sterile $30 \mathrm{mM}$ bicarbonate buffer at pH 7 prior to the uranium removal experiments. Batch experiments were performed in duplicate for each treatment and were initiated by addition of washed-cell suspension to $25 \mathrm{~mL}$ serum vials that contained bicarbonate-buffered medium with U(VI) $(100 \mu \mathrm{M})$ for a total liquid volume of $20 \mathrm{~mL}$ and a final concentration of $0.7 \mathrm{mg}$ (dry weight) cells $\mathrm{UFO} 1 / \mathrm{mL}\left(\sim 10^{8}\right.$ cells $\left./ \mathrm{mL}\right)$. Dry cell weight analyses were performed by filtering $0.5 \mathrm{~mL}$ of sample through a preweighed $0.2 \mu \mathrm{m}$ Supor ${ }^{\circledR}$ membrane syringe filter (Gelman Acrodisc). Samples from cell free controls were also filtered to ensure no change in weight due to the buffer itself. The filters were dried at $60{ }^{\circ} \mathrm{C}$ for 3 days, until a constant weight was observed (Gerhardt et al., 1981). Uranium was added in the form of uranyl chloride trihydrate, $\mathrm{UO}_{2} \mathrm{Cl}_{2} \cdot 3 \mathrm{H}_{2} \mathrm{O}$ (Bodman, Aston, PA). The cell suspensions were incubated at $25^{\circ} \mathrm{C}$ and shaken at $75 \mathrm{rpm}$. For studies with AQDS, cells were re-suspended in $30 \mathrm{mM}$ bicarbonate buffer at
pH 7 containing $100 \mu \mathrm{M}$ AQDS (Fisher, Pittsburg, PA) along with the uranium $(100 \mu \mathrm{M})$. In addition to cell- and uranium-free controls, heat-killed cell controls were included in the experimental matrix. For heat-killed cell controls, aliquots of washed cell suspension were transferred to an anaerobic serum bottle in the glove box, sealed with butyl rubber septa, capped, crimped with an aluminum seal, and autoclaved prior to adding medium with $\mathrm{U}$ and AQDS. Each set of treatment conditions was prepared in duplicate, and the treatments containing cells $+100 \mu \mathrm{M} \mathrm{U}(\mathrm{VI})$, cells $+100 \mu \mathrm{M} \mathrm{U}(\mathrm{VI})+100 \mu \mathrm{M}$ AQDS, and cell-free controls were repeated in separate experiments to verify reproducibility.

Removal of U(VI) from solution was evaluated by monitoring U(VI) concentration in unfiltered samples $(0.2 \mathrm{~mL})$ withdrawn by syringe and needle and measured immediately by kinetic phosphorescence analysis (KPA). Samples were diluted with anoxic, deionized (DI) water 1000-fold, and $1 \mathrm{~mL}$ of the diluted sample was mixed with $1.5 \mathrm{~mL}$ of Uraplex complexing agent (Chemchek, Richland, WA) prior to analysis with a KPA instrument (Chemchek); KPA measurements were performed immediately following sample collection in order to minimize the potential for reoxidation to U(VI). Calibrations were performed using uranyl chloride solutions from 0 to $0.23 \mu \mathrm{M}$, yielding a $\mathrm{U}(\mathrm{VI})$ detection limit of $0.04 \mu \mathrm{M}$ with a precision of $\pm 5 \%$. Samples $(0.5 \mathrm{~mL})$ for inorganic phosphate $\left(\mathrm{P}_{\mathrm{i}}\right)$ analysis were withdrawn from the serum vials by syringe and needle and centrifuged at $10,000 \mathrm{~g}$ for $8 \mathrm{~min}$. Inorganic phosphate $\left(\mathrm{P}_{\mathrm{i}}\right)$ concentrations in the supernatant were determined spectrophotometrically using Phosver ${ }^{\circledR} 3$ Phosphate reagent (Hach, Loveland, CO) and measurement at $880 \mathrm{~nm}$ on a UV-Vis spectrophotometer (Milton Roy Company Spectronic ${ }^{\circledR}$ GENESYS $5^{\mathrm{TM}}$, Rochester, NY).

\subsection{Characterization of immobilized uranium phases}

\subsubsection{X-ray absorption spectroscopy (XAS)}

X-ray Absorption Near Edge Structure (XANES) and Extended X-ray Absorption Fine Structure (EXAFS) spectroscopic methods were employed to determine the oxidation state of uranium and local atomic structure around uranium atoms. For these experiments, uranium was added in the form of uranyl acetate dihydrate, $\mathrm{UO}_{2}\left(\mathrm{CH}_{3-}\right.$ $\mathrm{COO})_{2} \cdot 2 \mathrm{H}_{2} \mathrm{O}$ (Ted Pella, Inc., Redding, CA), because we were unable to obtain additional $\mathrm{UO}_{2} \mathrm{Cl}_{2} \cdot 3 \mathrm{H}_{2} \mathrm{O}$ for these studies and strain UFO1 is not capable of utilizing acetate as an electron donor. Samples for XANES and EXAFS were prepared using protocols similar to those described above for the uranium removal experiments, except for the scale-up to a total volume of $100 \mathrm{~mL}$ to obtain sufficient sample for analysis by XANES and EXAFS. Cells of strain UFO1 were grown on R2 broth for 18-24 h, harvested by centrifugation at $10,000 \mathrm{~g}$, washed three times, and resuspended in bicarbonate buffer free of added phosphate; all transfers were performed in an anaerobic glovebag. Aliquots of the washed cell suspension were added by syringe and needle to sterile, sealed $150-\mathrm{mL}$ vials to give a final volume of $100 \mathrm{~mL}$ in bicarbonate buffer containing $100 \mu \mathrm{M}$ $\mathrm{U}(\mathrm{VI})$, and in certain treatments, $100 \mu \mathrm{M}$ AQDS. Cell sus- 
pensions $\left(\sim 1 \mathrm{mg}\right.$ dry weight of cells $/ \mathrm{mL} ; \sim 10^{8}$ cells $\left./ \mathrm{mL}\right)$ were incubated 5-6 days with shaking at $25^{\circ} \mathrm{C}$.

To prepare the reacted samples for XANES/EXAFS, the $100 \mathrm{~mL}$ cell suspensions were transferred to $250 \mathrm{~mL}$ screwcap centrifuge tubes with rubber o-rings. These were centrifuged at $10,000 \mathrm{~g}$, and approximately $90 \mathrm{~mL}$ of the supernatant were discarded. The resulting cell pellets were resuspended in the remaining fraction of the spent reaction medium/supernatant. Approximately $10 \mathrm{~mL}$ of concentrated cell paste were transferred anaerobically to $15 \mathrm{~mL}$ serum vials, which were then sealed with rubber stoppers and crimped with aluminum caps. Vials were placed in anoxic secondary containers and shipped to the Stanford Synchrotron Radiation Lightsource (SSRL). At SSRL, the cell paste was centrifuged in order to obtain a moist pellet with an approximate volume of $250-500 \mu$ l. Pellets were harvested in $1.5 \mathrm{~mL}$ conical eppendorf tubes with screw cap and o-ring seal. All manipulations were performed under anaerobic conditions, and pelleted samples were stored in an anaerobic chamber until analysis.

Transmission- and fluorescence-geometry uranium LIII edge XANES and EXAFS spectra were collected at room temperature as described previously (Bargar et al., 2000; Redden et al., 2001; Bencheikh-Latmani et al., 2003) at SSRL Beam Line 11-2. Fluorescence data were recorded using a Lytle-type ionization chamber detector (Stern and Heald, 1979). A variable-exit geometry double-crystal $\mathrm{Si}(220)$ monochromator was detuned to mitigate harmonics in the X-ray beam. XANES and EXAFS spectra were reduced and processed using SixPACK software Version 0.60 (Webb, 2004, 2005). Monochromator calibration was performed using the $\mathrm{K}$ absorption edge of a $\mathrm{Y}$ foil, checked every few scans. The change in energy calibration observed throughout the entire data collection period was $0.1 \mathrm{eV}$. The spectra were modeled as linear combinations (LCs) of spectra from reference minerals thought likely to be representative of species in this system: $\mathrm{UO}_{2.00}$, obtained from David Clark at LANL, autunite $\left(\mathrm{Ca}\left(\mathrm{UO}_{2}\right)_{2}\left(\mathrm{PO}_{4}\right)_{2} \cdot 10 \cdot \mathrm{H}_{2} \mathrm{O}\right)$ corresponding to sample UHA-9 in Fuller et al. (2002), and cell-sorbed uranyl obtained from a previous study with $P$. fluorescens (Bencheikh-Latmani et al., 2003). Shell-by-shell fits to the EXAFS were performed using IFEFFIT (Newville, 2001). FEFF 8 (Rehr et al., 1992) phase and amplitude functions were used to fit the EXAFS.

\subsubsection{TEM-EDS elemental analysis}

In addition to XAS, transmission electron microscopy was used to characterize the precipitates formed in U(VI)containing cell suspensions, and energy dispersive spectroscopy coupled with TEM (TEM-EDS) was performed to provide an elemental analysis of precipitates formed. Samples were prepared anoxically for TEM-EDS as described previously (Sani et al., 2006). All sample preparation was performed in an anaerobic $\left(5 \% \mathrm{CO}_{2} ; \leqslant 5 \% \mathrm{H}_{2} ; \mathrm{N}_{2}\right.$ balance) glovebag (Coy Laboratory Products, Grass Lake, MI). Briefly, cell pellets were harvested by centrifugation of 1$3 \mathrm{~mL}$ aliquots from $100 \mathrm{~mL}$ batch cultures of UFO1 treated with U(VI) (as described above for XAS), washed in anoxic, sterile ultrapure water, and then fixed in an anoxic stock of $3 \%$ glutaraldehyde for a minimum of 12 hours.
Fixed cells were pelleted and washed three times in anoxic DI water, followed by a gradual ethanol dehydration series (33\%, 55\%, 70\%, 90\%, and 100\% ethanol). Cells were embedded in LR White resin (Electron Microscopy Sciences, Hatfield, PA), and polymerized at $60{ }^{\circ} \mathrm{C}$ overnight. Embedded samples were sectioned to $70 \mathrm{~nm}$ on an ultramicrotome (Leica Ultracut UCT; Leica Microsystems, Bannockburn, IL), and sections were mounted on 200-mesh copper grids coated with Formvar support film sputtered with carbon. Sections were examined using a JEOL 2010 high resolution TEM (JEOL, Peabody, MA) with a $\mathrm{LaB}_{6}$ filament at $200 \mathrm{kV}$ with resolution of $0.19 \mathrm{~nm}$. Elemental analysis was performed with an Oxford EDS system (Oxford Instruments) equipped with an SiLi detector coupled to the TEM, and spectra were analyzed with ISIS software (Oxford Instruments). Images were collected and analyzed using Digital Micrograph software (Gatan Inc., Pleasanton, CA).

\section{RESULTS AND DISCUSSION}

\subsection{Uranium removal and phosphate release experiments}

The decrease of soluble U(VI) in cell suspensions containing $0.7 \mathrm{mg}$ (dry weight) cells $\mathrm{UFO} 1 / \mathrm{mL}$ is shown in Fig. 1. The concentration of soluble U(VI) decreased in treatments containing live cells of strain UFO1 in all of the conditions tested. Time-series uranyl profiles for treatments with and without $10 \mathrm{mM}$ lactate were nearly identical, and the presence of lactate did not affect the U(VI) reduction kinetics, suggesting that lactate oxidation was not coupled to respiration of U(VI). Strain UFO1 does utilize lactate as an electron donor for fermentation (Ray, 2007), and the reduction of U(VI) may result from its use as an electron sink during fermentative metabolism. The removal of soluble $\mathrm{U}(\mathrm{VI})$ in the absence of an externally provided electron donor was previously reported for Cellulomonas isolates (Sani et al., 2002), and it was suggested that the use of an endogenous electron donor may have been responsible for soluble U(VI) removal via reduction reactions. Under growth conditions, microorganisms

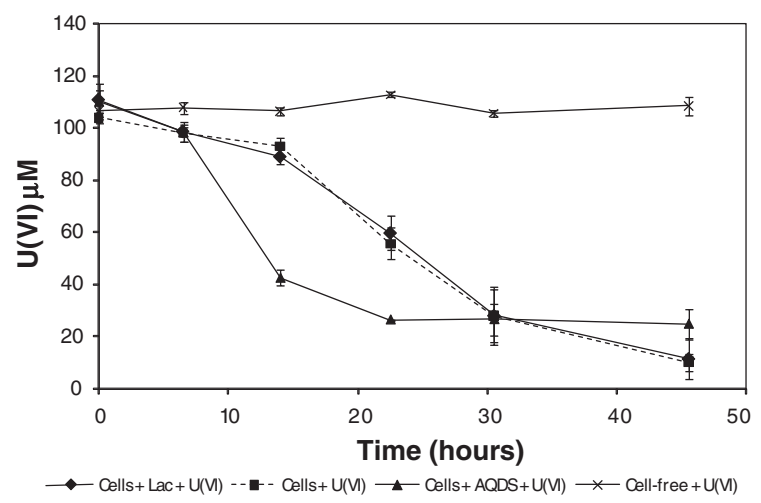

Fig. 1. Soluble U(VI) concentration in bicarbonate buffer over time. Symbols show the mean of duplicate analyses, and error bars indicate \pm 1 standard deviation. 
can accumulate energy storage polymers such as poly- $\beta$ hydroxybutyrate (PHB) that serve as carbon and energy reserves when other sources are not available (Bormann, 2000; White, 2000).

The presence of $100 \mu \mathrm{M}$ AQDS, in the absence of lactate, enhanced the removal rate of soluble U(VI) as compared to treatments without AQDS, although not the final extent. Reduction of AQDS by cell suspensions of strain UFO1 was indicated by a visible color change from transparent, pale yellow to orange (Liu et al., 2007). This suggests involvement of an endogenous electron donor for AQDS reduction by strain UFO1. The reduced form of AQDS, $\mathrm{AH}_{2} \mathrm{DS}$, can transfer electrons to $\mathrm{U}(\mathrm{VI})$. The $\mathrm{AH}_{2} \mathrm{DS}$ - mediated reduction of $\mathrm{U}(\mathrm{VI})$ has been reported for $D$. radiodurans $\mathrm{R} 1$ and $S$. putrefaciens (Fredrickson et al., 2000a,b). The effective reduction potentials for the AQDS-AH $\mathrm{AHS}_{2}(-2.40 \mathrm{~V})$ and the $\mathrm{UO}_{2}\left(\mathrm{CO}_{3}\right)_{3}^{4-}-\mathrm{UO}_{2}$ $(+0.078 \mathrm{~V})$ couples were calculated previously for similar experimental conditions (Fredrickson et al., 2000a,b), and results suggested that electron transfer from $\mathrm{AH}_{2} \mathrm{DS}$ to $\mathrm{UO}_{2}\left(\mathrm{CO}_{3}\right)_{3}^{4-}$ was thermodynamically favorable. The reduction of AQDS by strain UFO1 and enhanced removal rate of soluble $\mathrm{U}(\mathrm{VI})$ in AQDS-containing treatments suggest that uranium removal under these conditions may result from a shuttle-mediated reduction mechanism.

Changes in soluble ortho-phosphate concentrations over time are shown in Fig. 2. A low amount of soluble phosphate was measured in suspensions containing heat-killed cells $(44 \pm 3 \mu \mathrm{M})$, but there was no significant change in soluble phosphate concentration over the course of the experiment. There was no added source of phosphate present in the bicarbonate-buffered medium; this was confirmed by inclusion of a cell-free control in which the phosphate concentration was nearly zero $(3 \pm 0 \mu \mathrm{M})$. Taken together, these data suggest that the increase in phosphate concentrations seen in non heat-treated cell suspensions was biologically mediated. Differences were seen in the final concentration of ortho-phosphate for treatments incubated with and without U(VI). Washed cells incubated in the absence of U(VI) and without an added carbon source had the highest average concentration of inorganic soluble phosphate at the end of the experiment, $379 \pm 31 \mu \mathrm{M}$. In comparison, in cell suspensions where U(VI) was present (but no AQDS), the corresponding ortho-phosphate concentration was $243 \pm 1 \mu \mathrm{M}$. When $100 \mu \mathrm{M}$ AQDS was present along with the U(VI), the final ortho-phosphate concentrations were intermediate between the two, at $298 \pm 6 \mu \mathrm{M}$. Taken together, these findings suggest that the presence of $\mathrm{U}(\mathrm{VI})$ minimizes final average concentrations of inorganic phosphate in solution, while the potential for reductive processes seem to lessen this effect-i.e., more soluble phosphate remains.

Phosphate release by UFO1 may result from the hydrolysis of polyphosphate granules that were accumulated under favorable growth conditions (e.g., growth on R2 broth). Acinetobacter spp. have the ability to accumulate large amounts of phosphate as polyphosphate granules that can be used as an energy reserve under conditions where resources are limited (van Groenestijn et al., 1989); hydrolysis of polyphosphate produces ATP and inorganic phosphate is liberated from the cells (van Groenestijn et al., 1987). Cellulomonas sp. strain ES6 has also been shown to release phosphate under anaerobic conditions in the absence of an externally provided carbon source (Sivaswamy et al., 2011). The greater extent of phosphate release observed for UFO1 cells deprived of lactate, whether U(VI) was present or not, compared to cells provided with lactate (Fig. 2), is consistent with these findings.

\subsection{Characterization of immobilized uranium phases}

\subsection{1. $X A S$}

$\mathrm{X}$-ray absorption spectra were acquired for cell suspensions treated with $100 \mu \mathrm{M} \mathrm{U}(\mathrm{VI})$ in the absence and presence of $100 \mu \mathrm{M}$ AQDS after 5 days of incubation. The $\mathrm{U}$ $\mathrm{L}_{\mathrm{III}}$-edge XANES spectra for the samples were fit using a

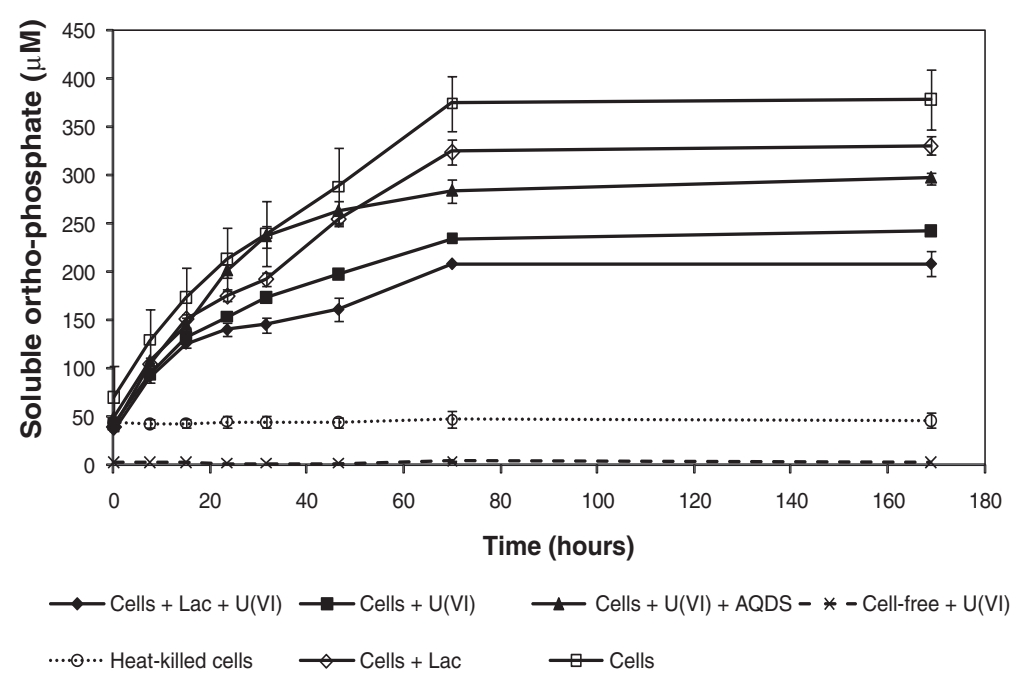

Fig. 2. Ortho-phosphate released by cells in the presence and absence of $100 \mu \mathrm{M} U(\mathrm{VI})$ in bicarbonate buffer over time. Symbols show the mean of duplicate analyses, and error bars indicate \pm 1 standard deviation. 
linear combination of spectra for two reference compounds, autunite and $\mathrm{UO}_{2.00}$ (Fig. 3). In the sample without AQDS, $17 \pm 10 \%$ of the uranium was found to be U(VI), and $83 \pm 10 \%$ was determined to be in the U(IV) oxidation state. In the sample treated with $100 \mu \mathrm{M}$ AQDS, the uranium was found to be $100 \pm 10 \% \mathrm{U}(\mathrm{IV})$. These results suggest that, regardless of the presence of an electron-shuttling moiety, uranium species after incubation with UFO1 were primarily in the reduced form (U(IV)) and reduction was the predominant mechanism for $\mathrm{U}(\mathrm{VI})$ removal under the conditions tested.

$\mathrm{U} \mathrm{L}_{\mathrm{III}}$-edge EXAFS spectra for UFO1 treated with $100 \mu \mathrm{M} \mathrm{U}(\mathrm{VI})$ in the presence and absence of AQDS are shown in Fig. 4. The EXAFS spectra for these samples differ significantly in the region between 6 and $9 \AA^{-1}$, where the positive antinode of the no AQDS spectrum has substantially larger amplitude than that of the $100 \mu \mathrm{M}$ AQDS sample. Differences between these two samples are expected from the results from XANES analyses. To test the hypothesis that the inventory of U(VI) in the no-AQDS sample was present as a U(VI) phosphate precipitate, its EXAFS spectrum was fit using a linear combination of EXAFS from autunite and the AQDS sample. The latter spectrum provides a representation of a fully reduced sample, i.e., no uranyl phosphate present. A good reproduction of the EXAFS of the no-AQDS sample was obtained. The fit indicated that $17 \%$ of $\mathrm{U}$ in the sample was consistent with a uranyl phosphate (autunite). This result agrees well with the XANES-derived conclusion that $17 \%$ of $U$ was present as U(VI) in this sample. To qualitatively assess the sensitiv-

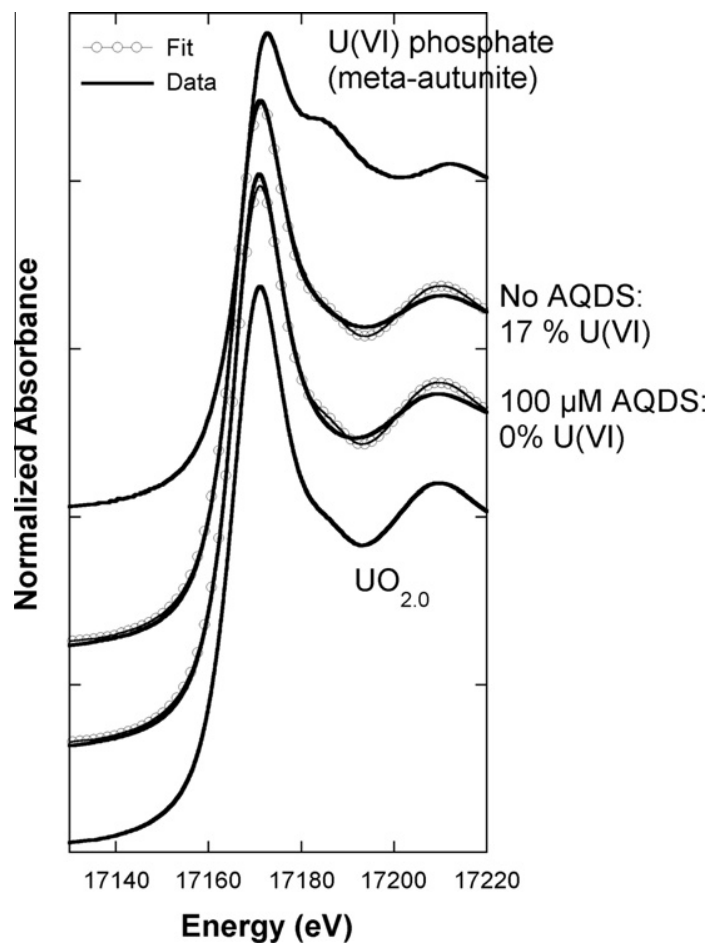

Fig. 3. $\mathrm{U} \mathrm{L} \mathrm{LII}_{\mathrm{II}}$-edge XANES spectra for uranium precipitates formed in cell suspensions of strain UFO, and for reference materials uraninite and meta-autunite. Dotted points show fit results. ity of the data to the fit, linear combination fits were also applied using schoepite and rutherfordine in place of autunite. As shown in Fig. EA-1, both fits were significantly worse than obtained with autunite. EXAFS spectra of U(VI) phosphates are generally similar to each other (Fuller et al., 2002); hence, this result does not lead to unambiguous identification of autunite, but does provide evidence for the presence of a member of the autunite mineral family. These results suggest that a partial explanation for the removal of soluble U(VI) from cell suspensions in the absence of an exogenous electron donor could be the precipitation of U(VI)-containing minerals; Sivaswamy previously reported the precipitation of a U(VI) phosphate phase by Cellulomonas strain ES6 (Sivaswamy et al., 2011). Linear combination fits were also attempted using reference spectra for U(VI) surface complexes on cells of $P$. fluorescens (Bencheikh-Latmani et al., 2003); these spectra were used because attempts to prepare analogous samples of U(VI) sorbed onto aerobic live and heat-killed cell suspensions of strain UFO1 for EXAFS analysis were unsuccessful. This component however did not appear to contribute to the no-AQDS EXAFS spectrum, suggesting that biomasssorbed U(VI) was below the detection limit in the samples.

The chemical and physical nature of the U(IV) in the AQDS-reacted sample (Fig. 4, spectrum a) remains unclear. Qualitative inspection of the Fourier Transform of the EXAFS spectrum from the $100 \mu \mathrm{M}$ AQDS sample (Fig. 5) shows the absence of the $3.8 \AA$ peak $(R+\delta R)$ that is characteristic of $\mathrm{UO}_{2}$ (Schofield et al., 2008), suggesting that uraninite is not present above the detection limit ( $c a 10$ $20 \%$ of total $\mathrm{U}$ ). If $\mathrm{UO}_{2}$ was not present, then it must be concluded that $\mathrm{U}(\mathrm{IV})$ is present as a molecular complex sorbed to biomass (Senko et al., 2007; Kelly et al., 2008; Bernier-Latmani et al., 2010; Fletcher et al., 2010) or present as a different mineral (Bernier-Latmani et al., 2010). Biomass on which sorption could occur is abundant, making this a reasonable conclusion. To test this hypothesis, shell-by-shell EXAFS fits were performed on the AQDS-reacted sample. The EXAFS are dominated by an $O$ shell with a corresponding FT peak at $c a 1.75 \AA(R+\delta R)(\mathrm{FT}$ peak values are phase-shifted relative to the physical arrangement of atoms and are thus denoted as $R+\delta R$ ). A secondary, smaller FT peak occurs at ca $2.9 \AA$ $(R+\delta R)$. EXAFS were fit up to $9.5 \AA^{-1}$. The spline was truncated at $10.2 \AA^{-1}$ to mitigate the impact of an $\mathrm{L}_{\mathrm{III}}-\mathrm{N}$ multi-electron excitation in the data at this location (Hennig, 2007). The $\mathrm{O}$ shell could be fit as a single shell of oxygens at $2.29 \AA$ (Table 1), which is generally consistent with 8-coordinated U(IV). Shells of neighboring atoms at distances beyond the $\mathrm{O}$ shells are expected to arise from strong metal binding functional groups present on biomass, i.e., carboxylate and phosphoryl (Kelly et al., 2001; Kelly et al., 2002; Senko et al., 2007), or neighboring shells of $\mathrm{P}$ or $\mathrm{U}$ atoms that may occur if solid phases such as uraninite or phosphates precipitated. Uraninite can be neglected because the characteristic FT peak at $c a 3.8 \AA$ (Schofield et al., 2008) is not present. Moreover, when the $2.9 \AA$ $(R+\delta R)$ FT peak was fit with a $\mathrm{U}$ shell, then a distance of ca $3.2 \AA$ was obtained, which is not physically realistic (Burns et al., 1997; Catalano and Brown, 2004). Uranyl 


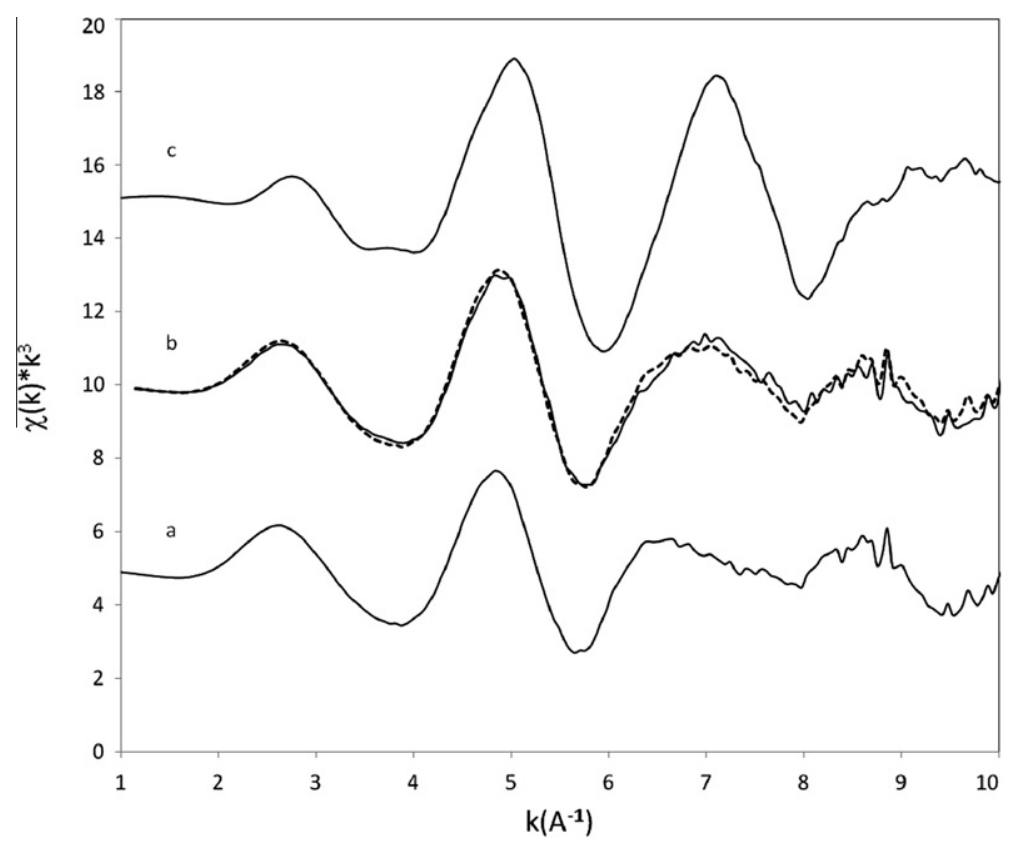

Fig. 4. $\mathrm{U}_{\mathrm{III}}$-edge EXAFS of uranium precipitates obtained from cell suspensions of strain UFO1 incubated with $100 \mu \mathrm{M} \mathrm{U}(\mathrm{VI})$ and $100 \mu \mathrm{M}$ AQDS (a) and in the absence of AQDS (b). Meta-autunite was used as a model compound (c). The dotted line in (b) shows the obtained linear combination fit of the data with spectra from (a) $81 \%$ and (c) $19 \%$, respectively (IFEFFIT $R$ factor $=0.031$ ).
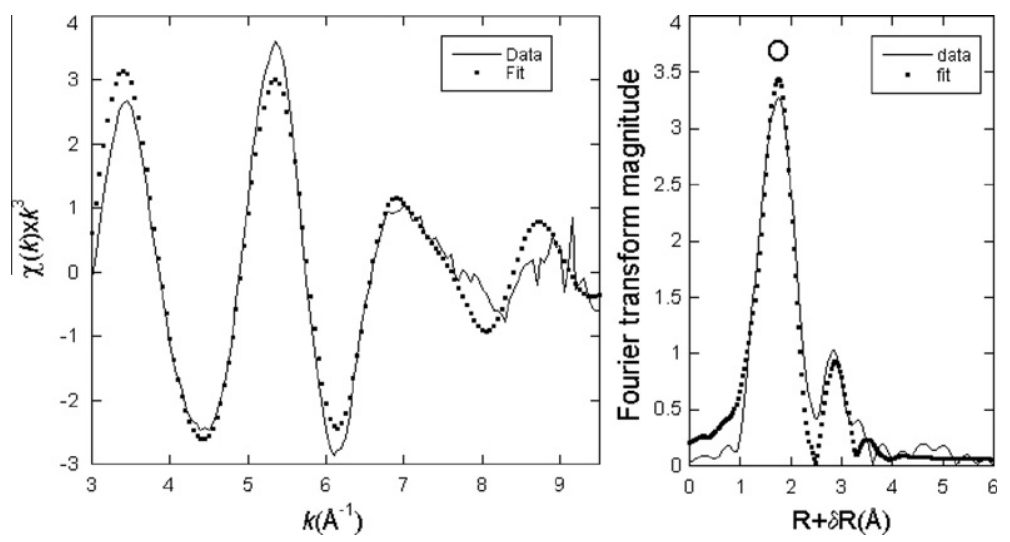

Fig. 5. $\mathrm{U} \mathrm{L}_{\mathrm{III}}$-edge EXAFS (left-hand side) and Fourier transform (right-hand side) of the $100 \mu \mathrm{M}$ AQDS sample.

Table 1

EXAFS fit results for the $100 \mu \mathrm{M}$ AQDS sample. One standarddeviation uncertainties in last reported digit are given in parentheses. Data fit range was $3 \leqslant k \leqslant 9 \AA^{-1}, 1 \leqslant R \leqslant 6 \AA$, and $S_{0}{ }^{2}$ was set to 0.9 . Columns 2 (C) and $3(\mathrm{P})$ represent alternative fits in which the corresponding frequency was first fit using $\mathrm{C}$, and then separately fit using $\mathrm{P}$.

\begin{tabular}{lllll}
\hline & $\mathrm{O}$ & $\mathrm{C}$ & or & $\mathrm{P}$ \\
\hline $\mathrm{N}($ atoms $)$ & $6.6(1.5)$ & $2.6(1.0)$ & & $0.9(5)$ \\
$R(\AA)$ & $2.30(2)$ & $3.41(4)$ & & $3.57(4)$ \\
$\sigma^{2}\left(\AA^{2}\right)$ & $0.017(3)$ & 0.006 & & 0.006 \\
\hline
\end{tabular}

phosphates can be ruled out because this sample contains almost exclusively U(IV). The $2.9 \AA(R+\delta R)$ FT frequency was therefore fit with either $\mathrm{P}$ and $\mathrm{C}$ shells. The statistical $R$ factors for these fits were 3.68 and 4.14, respectively (as calculated according to Eq. (1) in Hamilton (1965). The difference in these $R$ factors is not statistically significant, and therefore these results cannot be used to conclusively distinguish the identity of the 2 nd shell. The $3.59 \AA$ U-P distance is consistent with monodentate coordination of $U$ to phosphate groups (e.g., (Albering and Jeitschko, 1995; Dusausoy et al., 1996; Burns, 1999). A U-C shell at $3.41 \AA$ is consistent with ring structures that can be formed by multifunctional carboxylic acids (e.g., citrate). Both fits under-predict that amplitude of the frequencies between 2 and $3 \AA(R+\delta R)$, suggesting that an additional shell of atoms may be present at that location. We note that addition of a shell of either $\mathrm{C}$ atoms at $2.91 \AA$ or $\mathrm{P}$ atoms at 3.09 A fits this missing amplitude. Such shells do not signif- 
icantly improve the fit quality, and hence are not discussed further here.

\subsubsection{TEM-EDS elemental analysis}

In addition to XANES and EXAFS, TEM-EDS was employed to ascertain a chemical signature for uranium precipitates in cell suspensions of strain UFO1. Fig. 6 shows transmission electron micrographs of strain UFO1 cells following exposure to $100 \mu \mathrm{M} \mathrm{U}(\mathrm{VI})$ in the absence of AQDS in bicarbonate buffer. Regions of high contrast following the shape of the cell membrane (Fig. 6a and c) or in the shape of granules located within the cytoplasm (Fig. 6b) are assumed to be stable uranium precipitates. About 200 cells were examined, the majority of which appeared to have intracellular deposition of electron dense uranium precipitates with preferential deposition in the cytoplasmic area. The EDS analyses, while semi-quantitative, provided an indication of the chemical composition of the thin, needle-like structures within the cell shown in Fig. 6d and e. Following subtraction of the $\mathrm{P}$ background from electron dense areas (it was negligible in clean areas of the cell cytoplasm), the EDS analysis of the structures indicated a composition of $23 \% \mathrm{O}, 12 \% \mathrm{P}$, and $75 \% \mathrm{U}$ (element wt. $\%$ ), corresponding to at. $\%$ values of $79 \% \mathrm{O}, 18 \% \mathrm{P}$, and $13 \% \mathrm{U}$. The results suggest that the needle structures have a 1:1 atomic ratio for $\mathrm{U}: \mathrm{P}$, consistent with uranyl phosphate minerals such as autunite $\left(\mathrm{Ca}\left(\mathrm{UO}_{2}\right)_{2}\left(\mathrm{PO}_{4}\right)_{2}\right)$, although the EDS did not detect the presence of $\mathrm{Ca}$. Another possible phosphate structure could be $\left(\mathrm{UO}_{2}\right)_{3}(-$ $\left.\mathrm{PO}_{4}\right)_{2} \cdot 4 \mathrm{H}_{2} \mathrm{O}$ given that the $1: 1$ atomic $\mathrm{U}: \mathrm{P}$ ratio was an average for the sample, and variability exists within the range of measurements. The formation of such needle-like structures upon uranyl phosphate precipitation was reported previously for Cellulomonas sp. (Sivaswamy et al., 2011). The absence of visible evidence for the U(IV) molecular complexes implicated by the XAS analyses could be
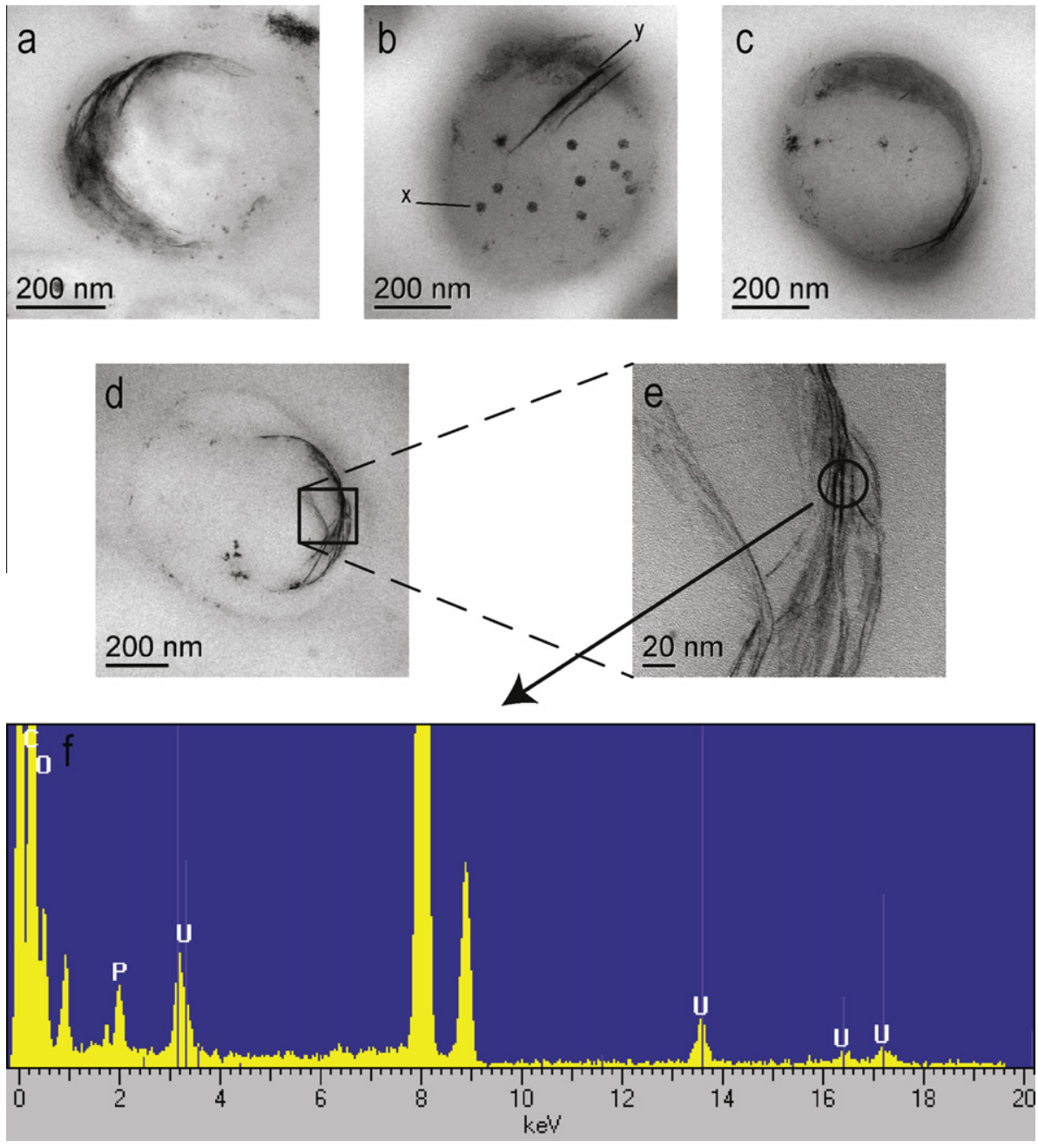

Fig. 6. ( $a, b$ and c)-Typical TEM cross-sections of cells treated with $100 \mu \mathrm{M} \mathrm{U}(\mathrm{VI})$ in the absence of AQDS showing intracellular uranium deposition along the plasma membrane and cytoplasm; in (b), $x$ denotes structures characteristic of U(IV) deposition, and y denotes needlelike structures characteristic of U(VI) phosphate precipitates; (d) shows the cross-section of a cell containing sheets of needle-like material; (e) shows magnification of the inset shown in (d); (f) EDS spectrum of the precipitates circled in (e). Copper peaks at 8-9 keV are characteristic of the grid. The spectrum shows clear $\mathrm{U}, \mathrm{P}$, and $\mathrm{O}$ signals. 

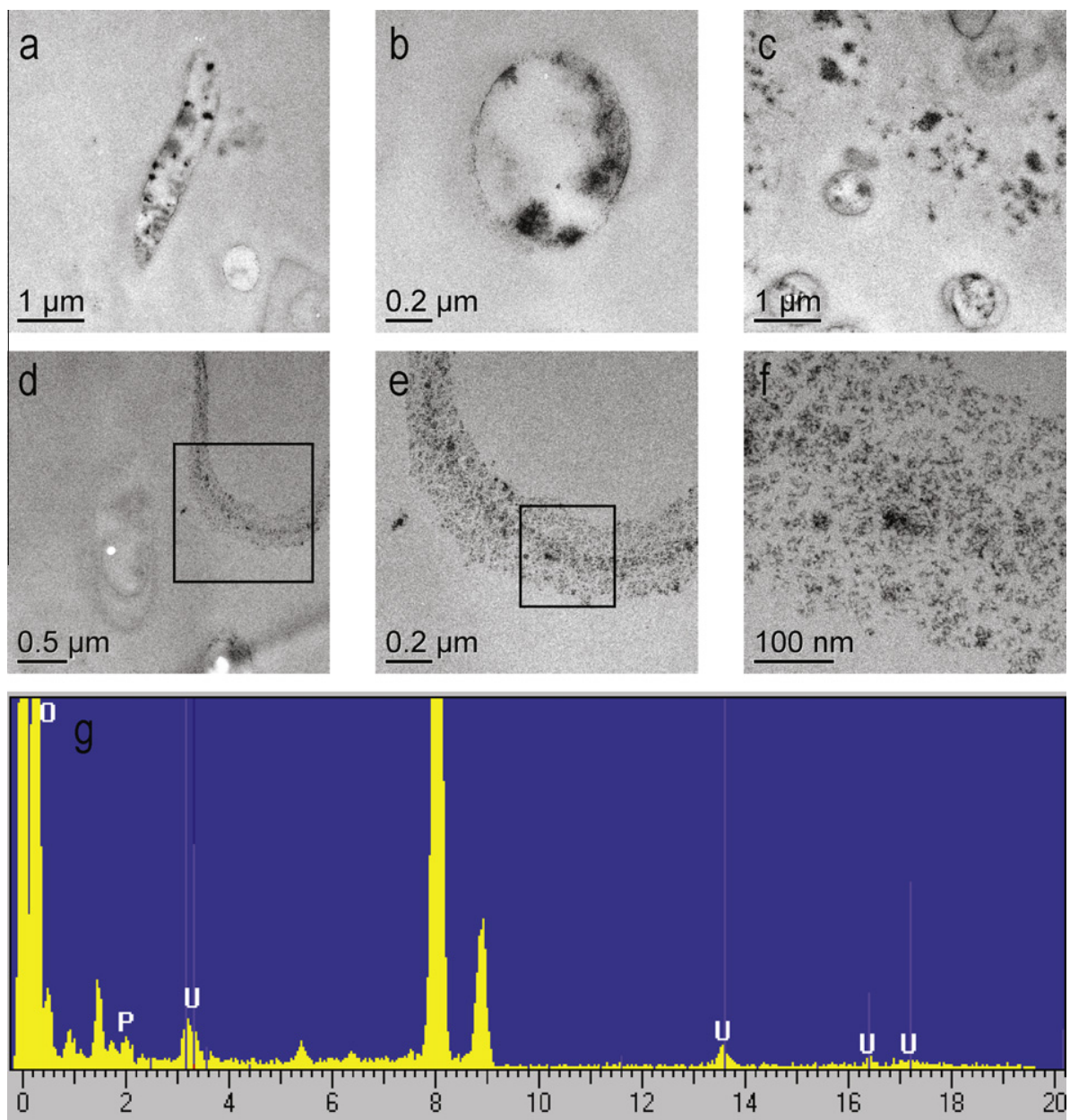

Fig. 7. (a, b and c)-Transmission electron micrographs of cells treated with $100 \mu \mathrm{M} \mathrm{U}(\mathrm{VI})$ and $100 \mu \mathrm{M}$ AQDS; (a and b) intracellular uranium deposition in the cytoplasm and cell membrane; (c) extracellular uranium deposition; (d, e and f-insets) extracellular uranium deposition characteristic of nanocrystalline uraninite and association with EPS matrix; (g) EDS spectrum of the precipitates (f) shows clear U and O signal. Copper peaks at $8-9 \mathrm{keV}$ are characteristic of the grid.

attributed to their being spread out over the biomass at relatively low concentrations, and thus undetectable with TEM.

TEM images of cells treated with U(VI) in the presence of AQDS are shown in Fig. 7. The majority of cells had a slight accumulation of electron dense material within their cytoplasm (Fig. 7a and b), and a small fraction of cells had periplasmic and outer membrane deposition. Less than $10 \%$ of the 200 cells examined from this treatment exhibited accumulation of the needle-like structures characteristic of uranium phosphate precipitates that were seen in the absence of AQDS (Fig. 6d and e). Extracellular accumulation of uranium material was evident in the AQDS-treated sample (Fig. 7c-e); uranium apparently associated with strands of extracellular polymeric substances (EPS) was observed in addition to the uranium material directly associated with the cells (Fig. 7e, inset from Fig. 7d). The EDS spectrum of the granules that comprised the majority of the uranium associated with the cells showed $\mathrm{U}, \mathrm{O}$, and $\mathrm{P}$ signals (Fig. $7 \mathrm{~g}$ ); however, the $\mathrm{P}$ signal was much lower than detected in the needle-like structures in Fig. 6e. The material appeared similar to previous observations of nanocrystalline uraninite particles bound to EPS (Dohnalkova et al., 2005; Marshall et al., 2006), although as noted previously, the EXAFS indicated that U(IV) was present predominantly as molecular complexes associated with biomass, and $\mathrm{UO}_{2}$, if present, represents only a small fraction of total $\mathrm{U}(\mathrm{IV})$ present in the sample.

\section{CONCLUSIONS}

The results presented here demonstrate the removal of soluble U(VI) by a novel environmental isolate, strain UFO1. Analysis of the solid phase precipitates associated with cell matter suggests that most of the U(VI) was reduced to U(IV) present as monomeric sorption complexes on the biomass. In the absence of the electron shuttling moiety, AQDS, some precipitation of uranyl phosphate minerals also occurred. TEM images combined with EDS spectra demonstrate that solid-phase uranium was accumulated both intra- and extracellularly. U(VI) removal by direct sorption to the cells appeared to be negligible. 
Ongoing experiments at the FRC have demonstrated that in situ bioreduction of $\mathrm{U}(\mathrm{VI})$ can result in levels of aqueous $\mathrm{U}$ that are in compliance with the maximum contaminant level (MCL); however, aqueous U concentrations rebound upon reentry of dissolved oxygen into the system (Wu et al., 2007). Due to this vulnerability associated with bioreduction schemes, phosphate mineral-based methods for uranium immobilization have recently gained more attention because of their lack of a requirement for redox control. However, a major challenge for phosphate-based remediation approaches is the distribution of phosphate in the subsurface; its extremely high reactivity can lead to clogging of the injection well and consequently a limited treatment radius (Wellman et al., 2006). Other researchers have proposed the use of precursor compounds such as glycerol-3-phosphate (Beazley et al., 2007; Shelobolina et al., 2009) or polyphosphate (Wellman et al., 2006) that can be transformed in situ to release phosphate in the subsurface. UFO1 has shown the ability to mediate removal of U(VI) from solution via both bioreduction and phosphate mineral precipitation. In the case of UFO1, internal reserves of phosphate were likely involved in the observed uranium immobilization, rather than degradation of an externally provided precursor compound. Additional research on the mechanisms involved in the phosphate mineral formation pathway is needed in order to ascertain whether this phenomenon can be controlled and enhanced to the levels needed for field-scale uranium remediation. If so, remediation approaches could potentially be developed with UFO1 or similar organisms that combine exploitation of the bioreductive mechanism for rapid but short-term $\mathrm{U}$ immobilization and reliance on the phosphate mineral precipitation mechanism for more robust long-term sequestration.

\section{ACKNOWLEDGEMENTS}

This work was supported by the Idaho National Laboratory (INL) and Inland Northwest Research Alliance (INRA); AER was supported by an INRA Subsurface Science Graduate Fellowship, and an INL Graduate Scholarship. Peyton and Sivaswamy were supported by the DOE Environmental Remediation Sciences Program. Support from the Stanford Synchrotron Radiation Lightsource, a national scientific user facility supported by the Department of Energy's Offices of Basic Energy Sciences and Biological and Environmental Research, provided significant contributions to this research. We thank Chris Fuller (US Geological Survey) for providing the spectrum of autunite and David Clark (Los Alamos National Laboratory) for providing the sample of $\mathrm{UO}_{2.00}$. A portion of the research was also performed using EMSL, a national scientific user facility sponsored by the Department of Energy's Office of Biological and Environmental Research and located at Pacific Northwest National Laboratory. We also thank George Redden for reviewing this manuscript and providing helpful comments. We thank Susan Glasauer and three anonymous reviewers for their help in improving the manuscript.

\section{APPENDIX A. SUPPLEMENTARY DATA}

Supplementary data associated with this article can be found, in the online version, at doi:10.1016/j.gca.2011. 02.040

\section{REFERENCES}

Albering J. H. and Jeitschko W. (1995) Crystal structure of diuranium monoxide diorthophosphate, $\left(\mathrm{U}_{2} \mathrm{O}\right)\left(\mathrm{PO}_{4}\right)_{2} . \mathrm{Z}$. Kristallogr. 210, 878.

Bargar J. R., Reitmeyer R., Lenhart J. J. and Davis J. A. (2000) Characterization of $\mathrm{U}(\mathrm{VI})$-carbonato ternary complexes on hematite: EXAFS and electrophoretic mobility measurements. Geochim. Cosmochim. Acta 64, 2737-2749.

Basnakova G., Stephens E. R., Thaller M. C., Rossolini G. M. and Macaskie L. E. (1998) The use of Escherichia coli bearing a phoN gene for the removal of uranium and nickel from aqueous flows. Appl. Microbiol. Biotechnol. 50, 266-272.

Beazley M. J., Martinez R. J., Sobecky P. A., Webb S. M. and Taillefert M. (2007) Uranium biomineralization as a result of bacterial phosphatase activity: insights from bacterial isolates from a contaminated subsurface. Environ. Sci. Technol. 41, 5701-5707.

Bencheikh-Latmani R., Bargar J. R. and Leckie J. O. (2003) Fate of uranyl in a quaternary system composed of uranyl, citrate, goethite, and Pseudomonas fluorescens. Environ. Sci. Technol. 37, 3555-3559.

Bernier-Latmani R., Veeramani H., Vecchia E. D., Junier P., Lezama-Pacheco J. S., Suvorova E. I., Sharp J. O., Wigginton N. S. and Bargar J. R. (2010) Non-uraninite products of microbial U(VI) reduction. Environ. Sci. Technol. 44, 94569462.

Bormann E.-J. (2000) Stoichiometrically calculated yields of the growth-associated production of polyhydroxybutyrate in bacteria. Biotechnol. Lett. 1437(6) (Author abstract).

Brooks S. C., Fredrickson J. K., Carroll S. L., Kennedy D. W., Zachara J. M., Plymale A. E., Kelly S. D., Kemner K. M. and Fendorf S. (2003) Inhibition of bacterial U(VI) reduction by calcium. Environ. Sci. Technol. 37, 1850-1858.

Burns P. C., Ewing R. C. and Hawthorne F. C. (1997) The crystal chemistry of hexavalent uranium: polyhedron geometries, bond-valence parameters, and polymerization of polyhedra. Can. Mineral. 35, 1551-1570.

Burns P. C. (1999) The crystal chemistry of uranium. Rev. Mineral. Geochem. 38, 23-90.

Catalano J. G. and Brown, Jr., G. E. (2004) Analysis of uranylbearing phases by EXAFS spectroscopy: interferences, multiple scattering, accuracy of structural parameters, and spectral differences. Am. Mineral. 89, 1004-1021.

Chang Y. J., Long P. E., Geyer R., Peacock A. D., Resch C. T., Sublette K., Pfiffner S., Smithgall A., Anderson R. T., Vrionis H. A., Stephen J. R., Dayvault R., Ortiz-Bernad I., Lovley D. R. and White D. C. (2005) Microbial incorporation of 13Clabeled acetate at the field scale: detection of microbes responsible for reduction of U(VI). Environ. Sci. Technol. 39, 9039-9048.

Dohnalkova A., Marshall M. J., Kennedy D. W., Gorby Y. A., Shi L., Beliaev A. S., Apkarian R. and Fredrickson J. K. (2005) The role of bacterial exopolymers in metal sorption and reduction. Microsc. Microanal. 11, 116-117.

Dusausoy Y., Ghermani N. E., Podor R. and Cuney M. (1996) Low-temperature ordered phase of $\mathrm{CaU}\left(\mathrm{PO}_{4}\right)_{2}$; synthesis and crystal structure. Eur. J. Mineral. 8, 667-673.

Elless M. P. and Lee S. Y. (1998) Uranium solubility of carbonaterich uranium-contaminated soils. Water Air Soil Pollut. 107, 147-162.

Fayek M., Harrison T. M., Grove M. and Coath C. D. (2002) A rapid in situ method for determining the ages of uranium oxide minerals: evolution of the cigar lake deposit, Athabaska Basin. In Frontiers in Geochemistry: Global Inorganic Geochemistry 
(ed. W. G. Ernst). Bellwether Publishing, Ltd. for the Geological Society of America, Columbia, MD.

Finneran K. T., Anderson R. T., Nevin K. P. and Lovley D. R. (2002) Potential for bioremediation of uranium-contaminated aquifers with microbial U(VI) reduction. Soil Sed. Contam. 11, 339-357.

Fletcher K. E., Boyanov M. I., Thomas S. H., Wu Q., Kemner K. M. and Löffler F. E. (2010) U(VI) reduction to mononuclear U(IV) by Desulfitobacterium species. Environ. Sci. Technol. 44, 4705-4709.

Fowle D. A., Fein J. B. and Martin A. M. (2000) Experimental study of uranyl adsorption onton Bacillus subtilis. Environ. Sci. Technol. 34, 3737-3741.

Fredrickson J. K., Kostandarithes H. M., Li S. W., Plymale A. E. and Daly M. J. (2000a) Reduction of Fe(III), Cr(VI), U(VI), and $\mathrm{Tc}(\mathrm{VII})$ by Deinococcus radiodurans R1. Appl. Environ. Microbiol. 66, 2006-2011.

Fredrickson J. K., Zachara J. M., Kennedy D. W., Duff M. C., Gorby Y. A., Li S. W. and Krupka K. M. (2000b) Reduction of U(VI) in goethite $(\alpha-\mathrm{FeOOH})$ suspensions by a dissimilatory metal-reducing bacterium. Geochim. Cosmochim. Acta 64, 3085-3098.

Fuller C. C., Bargar J. R., Davis J. A. and Piana M. J. (2002) Mechanisms of uranium interactions with hydroxyapatite: implications for groundwater remediation. Environ. Sci. Technol. 36, 158-165.

Geipel G. (2005) Speciation of actinides. In Handbook of Elemental Speciation II: Species in the Environment, Food, Medicine, and Occupational Health (eds. R. Cornelis, J. Caruso, H. Crews and K. Heumann). John Wiley and Sons Ltd., West Sussex, England.

Gerhardt P., Murray R. G. E., Costilow R. N., Nester E. W., Wood W. A., Krieg N. R., and Phillips G. B. (1981) Manual of methods for General Bacteriology. American Society for Microbiology, Washington, D.C. 505 pp.

Gorby Y. A. and Lovley D. R. (1992) Enzymic uranium precipitation. Environ. Sci. Technol. 26, 205-207.

Gu B., Yan H., Zhou P. and Watson D. B. (2005) Natural humics impact uranium bioreduction and oxidation. Environ. Sci. Technol. 39, 5268-5275.

Hamilton W. C. (1965) Significance tests on the crystallographic R factor. Acta Crystallogr. 18, 502.

Hennig C. (2007) Evidence for double-electron excitations in the $\mathrm{L}_{3}$-edge X-ray absorption spectra of actinides. Phys. Rev. B 75, 035120 .

NABIR (2003) Bioremediation of metals and radionuclides what it is and how it works. In NABIR primer, second ed. (eds. T. C. Hazen, S. M. Benson, F. B. Metting, B. Faison, A. C. Palmisano and J. McCullough). Lawrence Berkeley National Laboratory, Berkeley, CA, pp. 1-78.

Istok J. D., Senko J. M., Krumholz L. R., Watson D., Bogle M. A., Peacock A., Chang Y. J. and White D. C. (2004) In situ bioreduction of technetium and uranium in a nitrate-contaminated aquifer. Environ. Sci. Technol. 38, 468-475.

Kelly S. D., Boyanov M. I., Bunker B. A., Fein J. B., Fowle D. A., Yee N. and Kemner K. M. (2001) XAFS determination of the bacterial cell wall functional groups responsible for complexation of $\mathrm{Cd}$ and $\mathrm{U}$ as a function of $\mathrm{pH}$. J. Synchrotron Radiat. 8, $946-948$

Kelly S. D., Kemner K. M., Fein J. B., Fowle D. A., Boyanov M. I., Bunker B. A. and Yee N. (2002) X-ray absorption fine structure determination of $\mathrm{pH}$-dependent U-bacterial cell wall interactions. Geochim. Cosmochim. Acta 66, 3855-3871.

Kelly S. D., Kemner K. M., Carley J., Phillips D., Jardine P., Watson D., Criddle C. S. and Wu W.-M. (2008) Uranium speciation in sediments before and after in situ bioreduction. Environ. Sci. Technol. 42, 1558-1567.
Langmuir D. (1978) Uranium solution-mineral equilibria at low temperatures with applications to sedimentary ore deposits. Geochim. Cosmochim. Acta 42, 547-579.

Liu C., Zachara J. M., Foster N. S. and Strickland J. (2007) Kinetics of reductive dissolution of hematite by bioreduced anthraquinone-2,6-disulfonate. Environ. Sci. Technol. 41, 7730-7735.

Lovley D. R. (1995) Bioremediation of organic and metal contaminants with dissimilatory metal reduction. J. Ind. Microbiol. 14, 85-93.

Macaskie L. E., Empson R. M., Cheetham A. K., Grey C. P. and Skarnulis A. J. (1992) Uranium bioaccumulation by a Citrobacter $\mathrm{sp}$. as a result of enzymically mediated growth of polycrystalline $\mathrm{HUO}_{2} \mathrm{PO}_{4}$. Science 257, 782-784.

Macaskie L. E., Bonthrone K. M., Yong P. and Goddard D. T. (2000) Enzymically mediated bioprecipitation of uranium by a Citrobacter sp.: a concerted role for exocellular lipopolysaccharide and associated phosphatase in biomineral formation. Microbiology 146, 1855-1867.

Marshall M. J., Beliaev A. S., Dohnalkova A. C., Kennedy D. W., Shi L., Wang Z., Boyanov M. I., Lai B., Kemner K. M., McLean J. S., Reed S. B., Culley D. E., Bailey V. L., Simonson C. J., Saffarini D. A., Romine M. F., Zachara J. M. and Fredrickson J. K. (2006) C-type cytochrome-dependent formation of U(IV) nanoparticles by Shewanella oneidensis. PLoS Biol. 4, 1324-1333.

Newville M. (2001) IFEFFIT: interactive XAFS analysis and FEFF fitting. J. Synchrotron Radiat. 8, 322-324.

N'Guessan A. L., Vrionis H. A., Resch C. T., Long P. E. and Lovley D. R. (2008) Sustained removal of uranium from contaminated groundwater following stimulation of dissimilatory metal reduction. Environ. Sci. Technol. 42, 2999-3004.

North N. N., Dollhopf S. L., Petrie L., Istok J. D., Balkwill D. L. and Kostka J. E. (2004) Change in bacterial community structure during in situ biostimulation of subsurface sediment cocontaminated with uranium and nitrate. Appl. Environ. Microbiol. 70, 4911-4920.

Nyman J., Gentile M. and Criddle C. (2007) Sulfate requirement for the growth of $\mathrm{U}(\mathrm{VI})$-reducing bacteria in an ethanol-fed enrichment. Biorem. J. 11, 21-32.

Petrie L., North N. N., Dollhopf S. L., Balkwill D. L. and Kostka J. E. (2003) Enumeration and characterization of iron(III)reducing microbial communities from acidic subsurface sediments contaminated with uranium(VI). Appl. Environ. Microbiol. 69, 7467-7479.

Ray A. E., Connon S. A., Sheridan P. P., Gilbreath J., Shields M., Newby D. T., Fujita Y. and Magnuson T. S. (2010) Intragenomic heterogeneity of the 16S rRNA gene in strain UFO1 caused by a $100 \mathrm{bp}$ insertion in helix 6. FEMS Microbiol. Ecol. 72, 343-353.

Ray A. E. (2007) Discovery and characterization of a novel anaerobe with a potential role in bioremediation of metalcontaminated subsurface environments. Dissertation, Idaho State University.

Reasoner D. J. and Geldreich E. E. (1985) A new medium for the enumeration and subculture of bacteria from potable water. Appl. Environ. Microbiol. 49, 1-7.

Redden G., Bargar J. and Bencheikh-Latmani R. (2001) Citrate enhanced uranyl adsorption on goethite: an EXAFS analysis. $J$. Colloid Interface Sci. 244, 211-219.

Rehr J. J., Zabinsky S. I. and Albers R. C. (1992) High-order multiple-scattering calculations of X-ray-absorption fine-structure. Phys. Rev. Lett. 69, 3397-3400.

Renninger N., Knopp R., Nitsche H., Clark D. S. and Keasling J. D. (2004) Uranyl precipitation by Pseudomonas aeruginosa via controlled polyphosphate metabolism. Appl. Environ. Microbiol. 70, 7404-7412. 
Riley R. G., Zachara J. M., and Wobber F. J. (1992) Chemical contaminants on DOE lands and selection of contaminant mixtures for subsurface research. In Office of Energy Research (ed. DOE). US Department of Energy, Washington, DC

Sani R. K., Peyton B. M., Smith W. A., Apel W. A. and Petersen J. N. (2002) Dissimilatory reduction of $\mathrm{Cr}(\mathrm{VI}), \mathrm{Fe}(\mathrm{III})$, and U(VI) by Cellulomonas isolates. Appl. Microbiol. Biotechnol. 60, 192199.

Sani R. K., Peyton B. M., Amonette J. E. and Geesey G. G. (2004) Reduction of uranium(VI) under sulfate-reducing conditions in the presence of $\mathrm{Fe}(\mathrm{III})-(\mathrm{hydr})$ oxides. Geochim. Cosmochim. Acta 68, 2639-2648.

Sani R. K., Peyton B. M. and Dohnalkova A. (2006) Toxic effects of uranium on Desulfovibrio desulfuricans G20. Environ. Toxicol. Chem. 25, 1231-1238.

Schofield E. J., Veeramani H., Sharp J., Suvorova E., BernierLatmani R., Mehta A., Stahlman J., Webb S. M., Clark D. L., Conradson S. D. and Bargar J. R. (2008) Structure of biogenic $\mathrm{UO}_{2}$ produced by Shewanella oneidensis, strain MR-1. Environ. Sci. Technol. 42, 5600-5606.

Senko J. M., Istok J. D., Suflita J. M. and Krumholz L. R. (2002) In-situ evidence for uranium immobilization and remobilization. Environ. Sci. Technol. 36, 1491-1496.

Senko J. M., Kelly S. D., Dohnalkova A. C., McDonough J. T., Kemner K. M. and Burgos W. D. (2007) The effect of U(VI) bioreduction kinetics on subsequent reoxidation of biogenic U(IV). Geochim. Cosmochim. Acta 71, 4644-4654.

Shelobolina E. S., Konishi H., Xu H. and Roden E. E. (2009) U(VI) sequestration in hydroxyapatite produced by microbial glycerol 3-phosphate metabolism. Appl. Environ. Microbiol. 75, 5773-5778.

Sivaswamy V., Boyanov M. I., Peyton B. M., Viamajala S., Gerlach R., Apel W. A., Sani R. K., Dohnalkova A., Kemner K. M. and Borch T. (2011) Multiple mechanisms of uranium immobilization by Cellulomonas sp. strain ES6. Biotechnol. Bioeng. 108, 264-276.

Spear J. R., Figueroa L. A. and Honeyman B. D. (1999) Modeling the removal of uranium $\mathrm{U}(\mathrm{VI})$ from aqueous solutions in the presence of sulfate reducing bacteria. Environ. Sci. Technol. 33, 2667-2675.

Stern E. A. and Heald S. M. (1979) X-ray filter assembly for fluorescence measurements of X-ray absorption file structure. Rev. Sci. Instrum. 50, 1579-1583.

Suzuki Y. and Banfield J. F. (2004) Resistance to, and accumulation of, uranium by bacteria from a uranium-contaminated site. Geomicrobiol. J. 21, 113-121.

Suzuki Y., Kelly S. D., Kemner K. M. and Banfield J. F. (2003) Microbial populations stimulated for hexavalent uranium reduction in uranium mine sediment. Appl. Environ. Microbiol. 69, 1337-1346.
Suzuki Y., Kelly S. D., Kemner K. M. and Banfield J. F. (2004) Enzymatic U(VI) reduction by Desulfosporosinus species. Radiochim. Acta 92, 11-16.

Thomas R. A. P. and Macaskie L. E. (1996) Biodegradation of tributyl phosphate by naturally occurring microbial isolates and coupling to the removal of uranium from aqueous solution. Environ. Sci. Technol. 30, 2371-2375.

van Groenestijn J. W., Deinema M. H. and Zehnder A. J. B. (1987) ATP production from polyphosphate in Acinetobacter strain 210A. Arch. Microbiol. 148, 14-19.

van Groenestijn J. W., Bentvelsen M. M., Deinema M. H. and Zehnder A. J. (1989) Polyphosphate-degrading enzymes in Acinetobacter spp. and activated sludge. Appl. Environ. Microbiol. 55, 219-223.

Vrionis H. A., Anderson R. T., Ortiz-Bernad I., O’Neill K. R., Resch C. T., Peacock A. D., Dayvault R., White D. C., Long P. E. and Lovley D. R. (2005) Microbiological and geochemical heterogeneity in an in situ uranium bioremediation field site. Appl. Environ. Microbiol. 71, 6308-6318.

Webb S. M. (2004) Sam's Interface for XAS Package (SixPACK) Homepage. Available from: $<$ http://home.comcast.net/ sam_webb/sixpack.html $>$.

Webb S. M. (2005). SIXpack: a graphical user interface for XAS analysis using IFEFFIT. Phys. Scr. 1011. Available from: $<$ http://iopscience.iop.org/1402-4896/2005/T115/305/>.

Wellman D. M., Icenhower J. P. and Owen A. T. (2006) Comparative analysis of soluble phosphate amendments for the remediation of heavy metal contaminants: effect on sediment hydraulic conductivity. Environ. Chem. 3, 219-224.

White D. (2000) The Physiology and Biochemistry of Prokaryotes. Oxford University Press, New York, NY.

Wu W. M., Carley J., Gentry T., Ginder-Vogel M. A., Fienen M., Mehlhorn T., Yan H., Caroll S., Pace M. N., Nyman J., Luo J., Gentile M. E., Fields M. W., Hickey R. F., Gu B., Watson D., Cirpka O. A., Zhou J., Fendorf S., Kitanidis P. K., Jardine P. M. and Criddle C. S. (2006) Pilot-scale in situ bioremedation of uranium in a highly contaminated aquifer: 2 . Reduction of $\mathrm{U}(\mathrm{VI})$ and geochemical control of U(VI) bioavailability. Environ. Sci. Technol. 40, 3986-3995.

Wu W. M., Carley J., Luo J., Ginder-Vogel M. A., Cardenas E., Leigh M. B., Hwang C., Kelly S. D., Ruan C., Wu L., VanNostrand J., Gentry T., Lowe K., Mehlorn T., Carroll S., Luo W., Fields M. W., Gu B., Watson D., Kemner K. M., Marsh T., Tiedje J., Zhou J., Fendorf S., Kitanidis P. K., Jardine P. M. and Criddle C. S. (2007) In situ bioreduction of uranium (VI) to submicromolar levels and reoxidation by dissolved oxygen. Environ. Sci. Technol. 41, 5716-5723.

Associate editor: Susan Glasauer 